\title{
King-Armstrong Unit per Deciliter
}

National Cancer Institute

\section{Source}

National Cancer Institute. King-Armstrong Unit per Deciliter. NCI Thesaurus. Code

C122209.

A unit of phosphatase concentration that can free one milligram of phenol from

disodium phenylphosphate at standard conditions, per unit volume of the mixture equal to one deciliter. 